\title{
CAN CHOOSING THE FORM OF A NAME BE AN ACT OF IDENTITY?
}

\author{
AUD-KIRSTI PEDERSEN \\ University of Tromsø
}

\section{A B S T RAC T}

This paper discusses if place names can be used to construct and express identity, with a focus on the Norwegian names of farms and parishes. Since the Norwegian Place Name Act came into existence in 1991, the many appeals in regard to official spellings as decided by the authorities give clear indication that Norwegians have different opinions of how the names of farms and parishes should be spelled compared to names referring to natural features. Many people prefer the spelling of names of natural features to be as close as possible to the dialectal pronunciation, whereas they prefer older, often ornamental spellings or spellings which differ from the pronunciation when it comes to the names of farms and parishes. This paper looks at the reasons for these attitudes towards the spelling of place names, and is highlighted by some theory pertaining to language and identity.

\section{[1] INTRODUCTION}

During the last decades, there has been quite a bit of sociolinguistic research on the possible connection between language and identity. The notion of "acts of identity" has successfully been introduced by researchers Robert Le Page and Andrée Tabouret-Keller (1985), and is based on the linguistic studies of various pidgin and Creole speaking communities. Out of the studies of these multilinguistic societies, the authors claim that linguistic behaviour can be looked upon "as a series of acts of identity in which people reveal both their personal identity and their search of social roles" (Le Page \& Tabouret-Keller 1985,14). This theory assumes that speech expresses a lot about the speaker's attitudes, values and search for their social roles (op.cit.). In this sense, language is looked upon as an expression of identity. Language users must have a common awareness of what values are connected to the different features of their language so that the language can function as an identity marker, and this awareness can be both conscious and unconscious (op.cit., 181).

Language functions not only as an expression of identity, but is also looked upon as an important and available resource for identity construction. According to sociolinguistic research, it seems as if certain parts of a language are used more 
for identity construction, while other parts are more an expression of identity (Pedersen 2001, 48). There is no dichotomy between these two characteristics of language and identity, and both should be taken into consideration when talking about language and identity.

Within onomastics, we have seen a growing interest over the past few years in discussing whether there could be a connection between place names and identity. Place names constitute part of a language, and as linguistic utterances, one should assume that place names in addition to other parts of a language can function as units in expressing or constructing identity. Since place names, in contrast to appellatives, denote an individual unit - a definite place on earth - this characteristic must also be taken into consideration when discussing the circumstances connected to place names and identity.

In Norway, there have been many experiences in which the official spelling of a place name is not accepted by the local inhabitants, especially as it applies to farm names. A disagreement between a farm owner and the authorities in regard to the spelling of a farm's name even led to a trial that ended up in the Norwegian Supreme Court in 1961 (NOU 1983:6, 42). How could a farmer's opinion towards a certain spelling of a name be understood? Could a desire to use a certain written form of a place name be highlighted by theories connected to language and identity? In this paper, I will try to discuss the various circumstances connected to this topic, and illustrate the discussion with some examples of Norwegian place names where public authorities and farm owners/local inhabitants have had differences of opinion to how place names should be spelled.

\section{[2] NAMES AND CONSTRUCTION OF IDENTITY}

As previously mentioned, quite a bit of sociolinguistic research has indicated that language is an important means in relation to the expression and construction of identity. Names make up an important part of language, although up until recently, there has not been much focus on what type of function place names may have in the expression or construction of identity. Helleland (2009) focuses on the impact that knowledge of place names has for an individual, and the fact that it is natural for a human being to have roots in the past and feel attached to the place names of their childhood. Place names are not only geographical addresses, but also mental maps of surroundings. A name reveals the features of a landscape or events of the past; thus, names convey information pertaining to both the present and the past. Helleland (op.cit., 30) argues the knowledge of place names in one's surroundings may give a feeling of confidence, and if a person obtains a deeper knowledge of the history and meaning of the names in a certain area, this may further contribute to a person's well-being. Helleland (ibid.) refers to the scholar Huldén, who has pointed to the social effect of people of knowing the same place names: "To be familiar with the same name is to know a little about each other. 
The names are social signals of solidarity." (Huldén 1994, 33). The knowledge of a place's name is linked to social relationships because a single person does not in fact need place names. Place names make up part of a communication system shared by a social group, and the names "function as a social consensus or a sort of an agreement reached over many generations" (Helleland 2009, 30).

These judgements focus on the impact that place names may have on the identity of a person, i.e. the construction of personal identity. It is well known that place names have been used as important tools in helping to create a national identity. In the former Soviet Union, up to half of all place names were replaced in order to establish a new identity for the vast territory of the USSR, and the place name changes "were directly related to the ideological, political and national policy of the authorities" (Saparov 2003, 181). In Norway, in the spirit of the Norwegianisation of the Saami and Kven minorities during the 19th and 20th centuries (Bull 2005), the place names of minority languages were, if possible, translated into Norwegian or left off on official maps. This strategy could be labelled as toponymic silence: the removal of native place names from maps in order to create a new understanding in the population with regard to the cultural situation in an area (Greenwald 2005, 26; Helander 2006, Helander 2008, 96 f.). In the following, we shall consider the possibilities of using place names as a means of expressing personal identity.

\section{[2.1] Linguistic variation and expression of identity}

A characteristic feature of speech is variation, and variation has to do with the fact that all human beings have several linguistic registers at their disposal. Variation in linguistic registers is related to communicative situations and the different features which may vary could be connected to external linguistic factors. A typical variation pattern is between features belonging to a formal or informal style. The recurring features in speech must be understood on the basis of rules applied to communication among the members of a certain linguistic society and the attitudes associated with various linguistic features. The so-called accommodation theory (e.g. Giles \& Powesland 1997 [1975]) has proved to be useful in helping to understand the individual usage of linguistic patterns, while the same is true of the theory about linguistic behaviour being understood in light of personal and social identity.

An example of linguistic variation is, for instance, the pronunciation /'fesk/ versus /'fisk/ "fish" in the Tromsø dialect. The pronunciation of a short /e/ shows that you follow the traditional dialect, a lowered quality of the vowel as is commonly found in North Norwegian dialects. The /e/-pronunciation connotes local values and emphasises the state of being Northern Norwegian (cf. in that previously one could hear jokes like - told by Norwegians from Oslo and the surrounding area - "What is 25 metres long and smells of fesk"? A bus filled with Northern 
Norwegians"). The pronunciation /'fesk/ in Tromsø shows that a person follows the traditional variety of the Tromsø dialect, and this pronunciation was commonly used until the 1970s and the establishment of the University of Troms $\varnothing$. From that point forward, Tromsø received many new immigrants with various Norwegian dialects or languages other than Norwegian. The local dialect has undergone many changes since then and one of these changes is the pronunciation /'fisk/, found in the variation of Norwegian that many look upon as the standard variety. The pronunciation /'fisk/ connotes urbanity and the state of being upto-date. Linguistic variation of this kind is thoroughly examined and documented in Norwegian as well as in many other languages, but the varying forms of Norwegian place names are not examined from a sociolinguistic perspective. Applied to place names, it would not be sufficient to only investigate the use of place names in speech, because the written form, if the place name has a written form, are important to language users.

In Sweden, Fridell (2006) has investigated the use of various forms of Swedish farm names in a region of Sweden from a sociolinguistic perspective, and he argues that the use of various forms, both written and dialectal, are stylistically motivated and that more or less all place names can possibly vary in terms of style. According to Fridell, the dialectal forms of place names are usually classified as low-style variants, whereas the written forms are usually thought of as high-style variants, although low-style forms can occur in writing and high-style forms in speech according to the context. It is well known that people in general have a far more positive attitude to spoken standard languages than to dialects and to written language versus speech (e.g. Pedersen 2001, 46; Trudgill \& Giles 1978; Skjekkeland 2009). These circumstances are probably important for how the different forms of a place name are perceived. What could be further asked is whether a person's attitude to a certain form of a place name is an expression of his or her personal identity. Before I concentrate on this question, I will comment on the written and dialectal forms of place names and give some examples of reactions to the official spelling of place names.

\section{[3] WRITTEN AND DiALECTAL FORMS OF PLACE NAMES - REACTIONS}

Farm names have got both a dialectal and written form, and the pronunciation of a name in the Norwegian context is looked upon as the most original and truest form of a name, and the concept of inherited local pronunciation that is used for this form is also a legal concept in the Norwegian Place Name Act. Since farm names refer to property, and properties have financial value, the names have more often been written down than names of natural features. Many farm names have a long written tradition and the oldest forms go back to medieval times. The spelling of names has changed over the centuries according to the writing traditions dating back to the Old Norse time during the Danish period in our history (1450-1814) 
up until the present time. When the Danish period ended, it became a public endeavour to Norwegianise place names in order to bring the spelling more in accordance with the local pronunciation and the new Norwegian spelling principles. This Norwegianisation policy was part of establishing a new national and Norwegian identity after the Danish period. The Cadastre commission of 1878 was important in the process of the Norwegianisation of place names. The farm names received new Norwegianised spellings to be used on public maps and cadastres although the new spelling was not carried through in all contexts. The older Danish-influenced spellings of names were in many instances still used in land registers and for deeds of conveyance, and as a result of this, people became accustomed to these spellings and looked upon them as "correct" and "true". At the same time, people in general everyday speech used the inherited local pronunciation of the names, and a diglossic relationship, so to say, developed between the written forms and the dialectal forms used in speech. This is true for farm names, but not for place names which are labelled as nature-based names. In general, people prefer a spelling close to the dialect of nature-based names but, as for farm names, randomly chosen spellings from earlier times are commonly preferred, particularly if the name also functions as a family name (Larsen 2008, 359). Many are of the opinion that the Norwegianised forms are unfamiliar and have therefore been imputed by public authorities. The fact that the randomly arisen spellings of names from earlier times did not come into existence as a result of influence from local people is not emphasised by those who criticise the spellings based on the Place Name Act.

When the Place Name Act came into existence in 1991, public authorities were handed a legal instrument in order to make decisions concerning the official spelling of place names, and the act also gives landowners the right to express their opinion on the spelling of a name and to complain if they disagree with the authorised spelling. By the use of these means, many individuals have became involved in the public procedure of deciding the spelling of a name. In these matters, numerous controversies have arisen between farm owners and public authorities. The farm owners often want to retain the randomly chosen spellings of place names from the past, and as time went on many people started using these name forms for their family names. A common opinion is that the spelling of the family name should form the basis for the spelling of the farm name, even if the farm name is original and the family name is a secondary form.

The many legal cases involving a disagreement between farm owners and the authorities illustrates the fact that people care very much about the specific spellings of names. One could ask: why do they do this and what type of spellings do they want, and can we learn something about these people based on the spellings they want for place names? 
According to the Norwegian Place Name Act, the spelling of an inherited place name should be decided on the basis of the local pronunciation and should generally follow the spelling principle as used in the orthography of the Norwegian written standards (cf. \$4, first section of the Place Name Act). As a basic rule, a name should have just one spelling, although an exception could be made if, e.g. two or more spellings are well established or there is a strong local interest in the use of two or more forms of a name (cf. $\S 4$, second section). As previously stated, many have a strong distaste for using the orthography of farm names based on the inherited local pronunciation and this distaste is nothing new. In the work with the cadastre at the end of the 19th century, Rygh found that many had a negative attitude towards inherited local pronunciations:

Det lader til, at Bygdeudtalens Former, som daglig bruges af Bygdens Befolkning I indbyrdes Samkvem, opfattes som Former af lavere Rang, der ere gode nok til dagligdags Brug, men som det ikke er sømmeligt at anvende i Skrift eller i Samtale med Folk, der ikke selv tale vedkommende Bygds Maal (Rygh (1990 [1897])).

[It seems that the pronunciation forms that are used on a daily basis by the local population in communicating amongst themselves are seen as lower-status forms which are good enough for everyday use, but are not proper to use in writing or conversation with people who do not themselves speak the dialect of the locale in question.]

Today, more than 100 years later, the situation is to a large extent the same, but nevertheless the inherited local pronunciation, despite its low prestige, has remained more or less unchanged over time. One reason could be that the different forms of place names function within different linguistic domains. In informal contexts and in speech, the inherited local pronunciation can be used but if people give e.g. their address, a written form of the name is most likely to be given, and if a name is referred to in another context other than the very local context of name users, a form based on the written language is most likely to be used. A typical example is the distribution of definite and indefinite forms in place names. The definite form is used in informal contexts, whereas the indefinite is used for more formal situations. In writing, the indefinite form is generally used.

\section{[3.1] Attitudes towards different forms of place names - some examples} Bervik/Bervika - Definiteness as stylistic marker

A typical statement which illustrates the relationship between the formal and informal style in the use of names is "De heite Bervik /"bærvik/, men vi sei no bære Bervika /"bærvika/" ("It is called Bervik, but we just say Bervika"). Bervik(a) is the name of a farm in Hadsel municipality of Nordland County. The first part 
of the sentence refers to the use of an indefinite form when writing the name in a formal context and the expression "de heite" ('it is named, called') is likely to reveal an attitude of a "correct" form of the name, whereas the inherited local pronunciation /'bærvika/ belongs to a colloquial and informal context among people familiar with the name. The postposed definite article in the Nordic languages originally had a colloquial and informal style (Lundeby 1965, 21). In place names, the indefinite form is "gammal, ærverdig, smakar av skriftspråk og høgre stil" [old, honourable, tastes of written language and higher style], whereas the definite form "er ung, folkeleg og reint kvardagsleg i tonen" [is young, plain and quite colloquial in style] (Muri 1982 in (Haslum 2003, 78)).

\section{Finnkroken/Finnkrokan - The local inherited pronunciation is "wrong"}

In Karlsøy municipality in Troms County, we find the name /"finkrukan/, which is the name of a farm and a parish. The written form based on the pronunciation gives the spelling as Finnkrokan (Finn-, from finn m. 'Saami'; -krokan, def. pl. of krok m. 'bended landscape'), but the people in the parish prefer the spelling Finnkroken (def. sg.) since over time, the name has been written mostly in the definite singular form. In the 1990s, the local inhabitants filed a lawsuit in order to get the spelling Finnkrokan taken out of use and off public maps. Some even were of the opinion that the correct spelling was Finkroken (Fin-, fin adj. 'fine'), because in earlier times the spelling that was used was Fiinkrogen (Fiin-, older orthography of fin adj., krog older spelling, from Danish, of krok f.). The inherited local pronunciation was repudiated or referred to as being incorrect because it differed from the spelling of the name Finnkroken!

\section{Mesøy/Messøya - The local inherited pronunciation is irrelevant}

In Meløy municipality in Nordland County, the Norwegian Mapping and Cadastre Authority (NMCA) caused some resentment in 2009 when they decided to use the spelling Messøya for the pronunciation /"mæsøya/ (name of an island, farm and parish). Despite different spellings throughout the years, people had become used to the spelling as Mesøy and wanted to continue using this form. The Mesøy grendelag ['the Mesøy neighbourhood committee'] has appealed against the decision of the spelling Messøya and had, as of 5.5.2009, collected 201 signatures in support of their view. A great deal of work has been put into documenting the spellings in the past, but the inherited local pronunciation is not particularly emphasised. The Mesøy grendelag comments that NMCA has decided the spelling of the name "med begrunnelse i hht. lokal, nedarvet uttale. Dette er vi uenige i" [with justification in accordance with local inherited pronunciation. We disagree with this] (Mesøyinfo 2009). From within local quarters the local inherited pronunciation is not stated exactly; it is only said that the local population disagree with basing 
the spelling of the name on the pronunciation. This is yet another example that illustrates the normative force of written language.

Aune/Aun - repudiation of the inherited local pronunciation

In legal cases concerning the spelling of names, the result is often that the cases turn out to be unsolvable. The diglossic situation between the dialectal pronunciation and the written form can be changed, and the supporters of a certain written form may be able to deny the use or even the existence of the inherited local pronunciation. This is done for tactical reasons as the Norwegian Place Name Act claims that the spelling should be based on the inherited local pronunciation. When a spelling based on the pronunciation is not wanted, one strategy is to deny that the pronunciation exists. This was done in the case of Aun or Aune, a farm and parish name found in Harstad municipality in Troms County (http://aune.no). The Aune supporters denied as time went on that /'øun/ was the inherited local pronunciation, even though a video recording proved that this exact pronunciation was used by one of the "Aune-people" who had said /'øun/ at an earlier point before the case had been exaggerated and had reached a state of gridlock.

\section{Local controversies canalised into place name forms}

The case of Aun/Aune fully demonstrated that local controversies or differences that originally had nothing to do with a place name could be transformed into a dispute concerning the spelling of a name. The parish of Aun has a high proportion of Baptists and the local leader of the Baptists was an active force in this case. As time went on the case turned into a dichotomy between the Baptists and their supporters, who advocated the spelling as Aune, and non-Baptists and their supporters who, based on the inherited local pronunciation of /'øun/, wanted the spelling to be Aun. This gave the case an added dimension, and one could say that there was a division within the parish along religious lines. The Aune directive started a petition, and it is obvious that the leader of the local Baptists put pressure on those who were urged to sign the petition. In the petition it was even insisted on that the local inherited pronunciation was /'øune/, and by the use of these means, the religious leader got the signatories of the petition to vouch for something that was not consistent with reality.

\section{Place names should have the orthography from the Danish period}

In 2008, many farmers from the Østre Toten municipality in Oppland County opposed the spelling of farm names as determined by the NMCA. The opposition towards these spellings has led to the formation of an organisation with the aim of promoting the farmers' view of how place names should be written. The reason for the founding of this organisation is that the Place Name Act determines that local organisations have the right to appeal decisions on the spelling of place 
names, and the farmers needed such an organisation in order to be able to file a collective appeal. A farmer only has the right to appeal decisions in regard to the spelling of the name of his/her own farm. The new organisation uses the name Navnebeskyttelsen Norge [Name Protection Norway]. Spellings that have caused a reaction are, e.g. Hol /'hu:l/, Hom /'hom/ and Kvem /'kve:m/, whereas the farmers prefer the spellings Hoel, Homb and Hveem. These names illustrate that the normalisation principles applied to Norwegian are not wanted by the farm owners. In general, a long vowel in Norwegian is marked in orthography by a single consonant following the vowel, although older spelling conventions are preferred by the local farmers: <oe> for /u:/ and <ee $>$ for /e:/. The consonantism <hv> is preferred instead of $\langle\mathrm{kv}>$ even if the pronunciation is $/ \mathrm{kv} /$, and the spelling $<\mathrm{mb}>$ is not supported by the pronunciation of a long $/ \mathrm{m} /$. Other such common deviations between current and older orthography are, e.g. $<$ aa, ii, ld, nd $>$ for $<a$, i, $\mathrm{ll}, \mathrm{nn}>,<\mathrm{ck} / \mathrm{ch}>$ for $<\mathrm{k}(\mathrm{k})>,<\mathrm{x}>$ for $<\mathrm{ks}>$ and $<\mathrm{sch}>$ for $<\mathrm{sj}$, skj $>-$ just to mention a few examples. An important reason for the preference of older spellings seems to be that older orthography adds a higher stylistic value to a name than current orthography does. Spellings such as Wiig, Wiik or Wich seem to be looked upon as more prominent than Vik, while the same is true for Dahl versus Dal, Moe versus Mo etc. Name statistics from Statistisk sentralbyrå (Statistics Norway), (SSB 2009) show that 10,047 people in Norway have a family name based on the lexeme vik ("cove" or "bay"), and out of that total, 5,217 of them do not use the spelling Vik but instead prefer eight other different written forms of the name. In the case of dal ("valley"), the distribution is 123 who use Dal and 11,644 who use Dahl. The name Mo has 1,603 people who use that spelling as opposed to 6,818 who spell it as Moe (from mo m. "heath" or "moor").

[4] CAN CHOOSING THE FORM OF A NAME TELL US SOMETHING ABOUT THE USER OF THE NAME?

The conditions referred to here are characteristic of a number of cases in relation to the names of farms and parishes in Norway, and one could even say that for these types of names there is a kind of diglossic relationship between the dialectal forms used in speech and the written forms. According to Hallaråker, the dialectal speech forms and the written forms existed separately of each other until the end of the 19th century, and in spite of fewer differences between the written spoken forms of the names after the revision of the cadastre led by Rygh, this difference continued (Hallaråker 1996, 36). Forms of names found in public documents:

[...] hadde ei særleg høgtid over seg. At dei var i strid med den lokale uttalen og rettskrivinga vi lærte på skulen, forsterka berre det høgtidlege draget ved dei. Dei nærma seg faktisk ei form for 
religiøst språk av den typen vi fann hos Brorson og Kingo (Hallaråker 1996, 37).

[...had a special solemnity. That they conflicted with the local pronunciation and the orthography we learned at school just strengthened their solemn character. In fact, they became close to a form of the type of religious language used by Brorson and Kingo.]

As long as the dialectal pronunciation is just found in speech, it seems to function as a normally acceptable situation for people in general but when the authorities, in accordance with the Place Name Act, suggest a spelling other than the accustomed spelling, many react in a negative manner. It is undesirable that the inherited local pronunciation should adopt a new domain - that is the written language and public domain. As a result, we can say that the so-called dialect "uprising" that took place in Norway in the early 1970s has not yet affected the use of the dialectal forms of farm names. The dialect forms used in speech still have low prestige, and people think that they are not suitable for use in the public domain.

Is this desire to write a place name in a certain way an act of identity, i.e. a means of expressing identity? According to Le Page \& Tabouret-Keller (1985), an act of identity is to reveal the identity and search for a social role. What do these people reveal and what do they search for? Probably there is more than one explanation. Some people may perceive the spellings from the Danish period as older and more genuine than the official spellings, and their attitudes could be interpreted as misunderstood expressions of local patriotism, identity and historicism. Another interpretation could be that the desire for using orthography from the Danish period differently from present orthography in the spelling of farm names as a desire to be associated with the values that the older spellings represent - a kind of "snob factor". Le Page and Tabouret-Keller (p. 181) say that "[t]he individual creates for himself the patterns of his linguistic behaviour as resembling those of the group or groups with which from time to time he wishes to be identified, or so as to be unlike those from whom he wishes to be distinguished". The spellings from the Danish period give a colour of age and, socially and culturally, these spellings might give the appearance of belonging to a formerly higher official culture. The spelling Wiig has a different stylistic value than Vik and if you come from the farm named Wiig, the spelling might convey the impression of being higher on the social ladder than somebody who comes from Vik. According to Bourdieu (1991), linguistic forms represent a symbolic value. To understand a certain symbolic value one has to know and understand the society in which a language is used. In order to be able to consider the symbolic value that the various forms of Norwegian place names could possibly contain for language users, 
we need knowledge of the past and present cultural and historical situation in Norway.

At the end of the 19th century, Garborg (Garborg 1982 [1877], 102 f.) argued that Norway was not one nation and that there was a marked division between common people and the elite, and each of them had their own language and culture. The language of the common people was the Norwegian dialects while Danish-Norwegian was the language of the elite. The Norwegian population of today cannot be divided like this, though one could argue that the attitudes towards the dialectal and written forms of farm names are rooted in the former division between the common people with low prestige and the elite people with high prestige. Many people look down on the values which are represented by the dialectally inherited forms of names and look to the older forms which arose out of a formerly elite culture, even if they are incorrectly written. The written language represented by this culture is in fact still widely respected. One indication of this is the way people spell their first names using obsolete orthography, for example, a "silent $h$ " in names such as Grethe and Brith or the name Thea, which is used by 7,844 persons versus 337 for the spelling Tea (SSB 2009) - the spelling Thea could of course also be looked upon as influenced by international trends. The inclination to show off with names is commented on by, among others, the linguist Finn Erik Vinje (2009). He has criticised the selection and spellings of the names for the children of Princess Märtha and her husband Ari Behn. ${ }^{1}$ Vinje uses words such as "latterlig navne-anstaltmakeri" ("ridiculous needless naming activity"), and says that the names are "kuriøse, eksotiske navn, [med] stumme bokstaver og fremmede skrivemåter" ("singular, exotic names with silent letters and strange spellings") (VG 2009). Another interpretation could be that spellings that diverge from the official orthography are preferred because a special or marked spelling of a name conveys a higher degree of proprialisation. Wetås argues that the onomasticon is organized in forms of prototypes, and that personal names are more prototypical of the group of proper names than place names (Wetås 2008, 76). The spelling Dahl is an explicit marker of a linguistic utterance that is a family name, whereas Dal could be both a family name and a place name. The spelling Dahl underlines the character of a name with a higher degree of semantic demotivation (op.cit., 78). In this example, it means that the lexical unit dal 'long hollow in the landscape' is not present in the spelling Dahl.

Human beings present themselves by using their first name, family name and sometimes also with the name of the place where they come from. One must assume that depending of what type of "category" we prefer to identify ourselves with, we will try to present ourselves in a way that others can identify us as we

[1] Their two girls are named Maud Angelica Behn and Emma Tallulah Behn. 
would like to be seen. For this purpose, we must use language as the means for our presentation.

Many have adopted older spellings of place names as family names, and approximately $70 \%$ of all Norwegian family names are based on the names of farms (Veka 2000,17). Many farmers want the spelling of their farm name to match the spelling of their family name even if the family name originates from the place name and not the opposite. By using this means, farmers try to transform their own identity to the place name even though the place name arose long before the family name, and has connections to a past with people and a time the people of today know nothing about. One could say that in this way the farmers confiscate a collectively inherited cultural heritage and try to connect place names to definite persons. In doing so, they introduce a personification to place names. This action reveals a weighing of the individual and personal dimension but ignores the fact that place names belong to a collective cultural context. The reason why people do this is probably because they feel emotionally attached to both the family and place name, thus forming the basis of the family name. The farmers create a link among the person, name and location. Place names refer to places in the world, and people feel an attachment to the places where they are from or have lived at for a long time. They feel that they are part of the place. Ponzetti says that:

Place attachment refers to the emotional connection formed by an individual to a physical location due to the meaning given to the site as a function of its role as a setting for experience. A range of thoughts, beliefs, attitudes and behavior, as well as feelings, are evoked through attachment to place. Thus, place attachment involves an elaborate interplay of emotion, cognition and behavior in reference to place. (Ponzetti 2003, 1)

Because people can feel attached to both a place and a place name, they probably feel they have "a right" to the name. Strictly speaking, a land owner does possess "a right" to a property because legally he or she possesses earth and ground belonging to a certain property. Another question is "the right" to a place name that refers to the property. If people have started using a place name as a family name, they will probably feel a stronger "right" to the name than if they do not use the place name as a family name. Larsen indicates that a family name creates a "we" feeling and a sense of social solidarity. He further argues that a name is a part of our identity, and if the feeling of identity is transferred to a place name that the family name is based on, people could look upon a change in the spelling of the name as an encroachment (Larsen 2008, 359). But the case of Aun/Aune shows that the attitude of feeling a "right" to decide the spelling of a place name is not necessarily only related to family names which are based on a place name. 
In this case, none of the most important parties had a family name based on this place's name.

\section{[5] CONCLUSION}

We have seen that place names, as well as other parts of language, can be used to construct and express identity and we have focused on the names of farms and parishes in Norway. Many Norwegians have demonstrated a strong desire for using certain spellings of names, and their actions can be accounted for as a means of expressing personal and social identity. An important factor of this desire is probably the respect for the written language and the respect for the values represented in society by the former elite of the country. It must also be underlined that even if the described pattern is common, not everybody in a society wants to use obsolete spellings of farm and parish names which differ from the inherited dialectal pronunciation. One could ask if the construction and expression of identity is something that can be found in all societies. I argue that this is so, although the relationship between place names and identity is probably not identical in every society. Since every society is unique, one must expect some functional variation depending on the society in question. Historical background and cultural conditions vary from society to society and from one time to another, and it is important to take these circumstances into consideration in order to acquire an understanding of how place names function in connection to the concept of identity. The Norwegian and Swedish societies are in many ways much the same today, but the history of these societies is different. In Staffan Fridell's $(2006,2009)$ investigation of the stylistic function of Swedish place names, he comments on the differences between these two societies (Fridell 2009, 68). In Sweden, the variation among different forms of place names can be analysed as a stylistic variation within a language, but in Norway this stylistic variation could be looked upon as a variation that originated from two languages - Norwegian and Danish. Since the late Middle Ages, speaking Danish in Norway functioned as a high status language versus the Norwegian dialects, which makes this an important fact to take into account for understanding the current situation in Norway today in terms of how people evaluate the different forms of place names. It is also important to be aware of the difference in function between the names of farms and parishes on the one hand, and names of natural features on the other. In the latter case, Norwegians generally prefer spellings to be close to the dialect forms whereas, as we have seen in this paper, the opposite is true in regard to the names of farms and parishes. The different strategies for spelling names could perhaps be understood in the light of the theory of proprialisation. The names of farms and family names are linked to each other, and the higher degree of propriality of family names is transmitted to farm names when people advocate the same spelling principles for these two groups of names. It could even be argued according to the theory 
of proprialisation that names of natural features have a lower degree of proprialisation than farm names, and at the other end of the scale are the family names. One could therefore assume that the higher the degree of propriality, the more important names are as identity markers (about proprialisation of place names, see also Bakken 1995, 137 f.). ${ }^{2}$

\section{REFERENCES}

Bakken, K. 1995. Leksikalisering av sammensetninger. En studie av leksikaliseringsprosessen belyst ved et gammelnorsk diplommateriale fra 13-tallet. Institutt for nordistikk og litteraturvitenskap. Det historisk-filosofiske fakultet. Universitetet i Oslo. Avhandling for graden doctor artium.

Bourdieu, P. 1991. Language and Symbolic Power. Cambridge, MA: Harvard University Press.

Bull, T. 2005. Special linguistic developments in 19th-century Norway. In Bandle, Oskar (main ed.): The Nordic Languages. An International Handbook of the History of the North Germanic Languages, vol. 2, 1468-1475. Berlin, New York: Walter de Gruyter.

Fridell, S. 2006. Ortnamn i stilistisk variation. Acta Academiae Regiae Gustavi Adolphie 95.

Fridell, S. 2009. Stylistic variation in place-names. In I nomi nel tempo e nello spazio. Atti del XXII Congresso internazionale di scienze onomastiche, Pisa, 28 agosto-4 settembre 2005, vol. 2, 61-68. Pisa.

Garborg, A. 1982 [1877]. Den ny-norske Sprog- og Nationalitetsbevcegelse. Et Forsøg paa en omfattende Redegjørelse, formet som polemiske Sendebreve til Modstrceverne. Noregs Boklag.

Giles, H. \& P. Powesland. 1997 [1975]. Accommodation Theory. In Coupland, Nikolas and Adam Jaworsky (eds.): Sociolinguistics. A Reader and Coursebook, 270-283. Houndmills: Macmillan.

Greenwald, J.E. 2005. Power in place-names: A case study of present day Waterford County, Ireland. A thesis presented to the faculty of the College of Arts and Sciences of Ohio University.

Hallaråker, P. 1996. Bunden og/eller ubunden form som normert skriftform i offisielle stadnamn. Namn og nemne 13. 35-51.

[2] I would like to thank Staffan Fridell for making me aware of the possible connection between the degree of proprialisation and spellings of names, and that there could be a relationship between degree of proprialisation and identity. 
Haslum, V. 2003. Artikkelløse stedsnavn i norsk talespråk. En studie i onomastikk og dialektologi. Nordisk institutt, Det historisk-filosofiske fakultet, Universitetet $\mathrm{i}$ Bergen. Avhandling for doctor artium-graden.

Helander, K.R. 2006. The theory of toponymic silence and Sámi place names during the growth of the Norwegian nation state. In Sáhkavuorru Place names and identities in multicultural contexts-symposias. Kárášjohka 17.-19.8.2006. Almmustahttojuvvome.

Helander, K.R. 2008. Namat dan nammii. Sámi báikenamaid dáruiduhttin Várjjaga guovllus Norgga uniovdnaáiggi loahpas. Dieđut 1.

Helleland, B. 2009. Place names as a means of landscape identity. In Jordan, Peter, Bergmann, Hubert, Cheetham, Catherine and Isolde Hausner (eds.): Geographical Names as a Part of the Cultural Heritage. Wiener Schriften zur Geographie und Kartographie, vol. 18, 25-31. Institut für Geographie und Regional-forschung der Universität Wien. Kartographie und Geoinformation.

Huldén, L. 1994. Ortnamnens upplevelsevärde [The value of experiencing placenames]. In Ulfsparre, Göran (ed.), Ortnamn värda att värda. Föredrag från Riksantikvarieämbetets symposium Ortnamnskultur. Stockholm 5-7 maj 1993, 32-37. Stockholm: Riksantikvarieämbetet.

Larsen, T. 2008. Reaktionen auf die Namenstandardisierung nach dem norwegischen Ortsnamengesetz. In Brylla, Eva \& Mats Wahlberg (eds.) in collaboration with Dieter Kremer \& Botolv Helleland. Proceedings of the 21st International Congress of Onomastic Sciences. Uppsala 19-24 August 2002, vol. 4, 355-360. Uppsala: Institutet för språk och folkminnen.

Le Page, R.B. \& A. Tabouret-Keller. 1985. Acts of identity. Cambridge: Cambridge University Press.

Lundeby, E. 1965. Overbestemt substantiv i norsk og de andre nordiske språk. Oslo, Bergen, Tromsø: Universitetsforlaget.

Mesøyinfo. 2009. Mesøy - Messøya. http://sites.google.com/site/mesoyinfo/Home-gml. (5.5.2009).

NOU. 1983:6. Stadnamn. noregs offentlege utgreiingar. Oslo, Bergen, Tromsø: Universitetsforlaget.

Pedersen, I.L. 2001. Talesprog som identitetsskaber og identitetsudtryk. Nordlit. Arbeidsstidsskrift i litteratur 10. 41-55. 
Ponzetti, J.J.Jr. 2003. Growing old in rural communities: A visual methodology for studying place attachment. Journal of Rural Community Psychology E6, Number 1. http://www.marshall.edu/jrcp/E6one_Ponzetti.htm (12.5.2009).

Rygh, O. 1990 [1897]. Hvad er der gjort i Noreg for at samle Materialer til Belysning af Landets Stedsnavne. Namn og nemne 7. 102-121. Published by Oddvar Nes.

Saparov, A. 2003. The alteration of place names and construction of national identity in Sovjet Armenia. Cahiers du Monde russe 44/1. 179-198. monderusse.revues.org/docannexe4079.html (16.4.2009).

Skjekkeland, M. 2009. Respekten for skriftspråket. Fæedrelandsvennen http://www.fvn.no/mening/kommentarer/article657780.ece (29.4.2009).

SSB. 2009. Statistisk sentralbyrå, Namnestatistikk.

http://www.ssb.no/emner/00/navn/index.html. (5.5.2009).

Trudgill, P. \& H. Giles. 1978. Sociolinguistics and linguistic value judgments: Correctness, adequacy and aesthetics. In Coppieters, Frank and Didier L. Goyvaerts (eds.): The functions of Language and Literature Studies. Ghent: Story-Scientia.

Veka, O. 2000. Norsk etternamnleksikon. Norske slektsnamn - utbreiing, tyding og opphav. Oslo: Det Norske Samlaget.

VG. 2009. VG Nett: Latterliggjør Märtha og Ari for bisarre navn. (About Finn Erik Vinje's criticism of names).

http://www.vg.no/nyheter/innenriks/artikkel.php?artid=536250. (22.1.2009).

Wetås, Å. 2008. Kasusbortfallet i mellomnorsk. Ein komparativ studie av proprialt og appellativisk materiale. Institutt for lingvistiske og nordiske studium, Det humanistiske fakultetet, Universitetet i Oslo. Avhandling for graden doctor artium.

AUTHOR CONTACT INFORMATION

Aud-Kirsti Pedersen

Faculty of humanities, social sciences and education

Department of language and linguistics

University of Tromsø

NO-9037 Tromsø

aud.kirsti.pedersen@uit.no 